\title{
ANTUNES, António Lobo. O meu nome é Legião. Lisboa: Dom Quixote, 2007.
}

Cid Ottoni Bylaardt Universidade Federal do Ceará

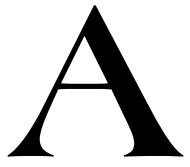

ntónio Lobo Antunes tem o costume de parafrasear Mallarmé afirmando que um livro não se faz com idéias, mas com palavras. O romancista afirma ainda que não tem nada na cabeça quando começa um livro, e que as palavras é que puxam as palavras, e assim o livro vai-se escrevendo. Na época em que lançou o livro Exortação aos crocodilos, Lobo Antunes dizia que a história o interessava cada vez menos. Hoje, oito romances depois, o ensinamento mallarmeano se impõe com cada vez mais força no texto do escritor português, e o chamado enredo, a estrela do romance tradicional, se dilui a cada narrativa que ele escreve.

O meu nome é Legião, romance (?) publicado em 2007, não tem personagens marcantes como a Maria Clara de Não entres tão depressa nesta noite escura, ou a
Marina de Boa tarde às coisas aqui em baixo, ou os amantes de Eu heide amar uma pedra. Não tem uma história emocionante como em $O$ manual dos inquisidores ou em $A$ morte de Carlos Gardel. O que a presente narrativa preserva dos livros anteriores é o trabalho da linguagem, que a cada livro faz-se mais presente, de forma mais contundente, na medida em que as outras categorias da narrativa se retiram paulatinamente. Esse processo de desnarrativização da escrita romanesca acentua-se de forma mais nítida a partir de Não entres tão depressa nesta noite escura, compondo o que se poderia chamar um terceiro momento na obra do escritor. O primeiro momento é composto pelos sete primeiros romances, em que o gênero se apresenta de maneira mais tangível em termos de trama, narrador e personagens, e mesmo 
em relação às noções de tempo e espaço. A segunda fase incluiria os romances de Tratado das paixões da alma axortação aos crocodilos, em que as mencionadas categorias começam a se fragmentar, sobressaindo a indefinição de vozes, a desmaterialização da trama narrativa e a encenação da linguagem.

Em O meu nome é Legião, o argumento é apresentado logo no primeiro capítulo: oito jovens delinqüentes de idades entre doze e dezoito anos cometem um latrocínio em um posto de gasolina. O relator é um velho policial, que recebe a missão de investigar o caso. Após a leitura desse capítulo, o leitor que não conhece Lobo Antunes tende a esperar os desdobramentos da ação em eventos relacionados por causa e efeito, como a identificação dos criminosos e seus motivos, os efeitos de sua ação sobre o corpo social e as conseqüências para os marginais. Quaisquer expectativas nesse sentido são frustradas pelo desenrolar dos relatos.

Do narrador dos três primeiros capítulos espera-se que ele prenda os criminosos, contando com uma pequena equipe, e relate objetivamente os acontecimentos. Sua escrita, entretanto, não consegue ater-se aos fatos, como também seu executor não cumpre sua missão de desbaratar a gangue, ou pelo menos não consegue relatar sua intervenção no caso. Ele culpa os negros e mestiços pelas desgraças sociais de Portugal, e questiona em seu relato a "justeza da política de imigração nacional". Pouco a pouco, digressões vão-se infiltrando no relatório, e o relator começa a colocar inadvertidamente suas emoções no texto, admitindo a fraqueza: "estou cônscio do erro e penitencio-me dele". ${ }^{1}$ Mesmo com toda essa consciência, o texto vai sendo tomado pelas lembranças do pai, da mãe e do padrasto, da filha, que não gosta dele e que ele visita um domingo por mês, e por ações pouco romanescas, como contar palitos num paliteiro de restaurante. Ele não suporta o que escreve, e após o terceiro capítulo cede a palavra. O que se tem daí em diante são depoimentos de várias pessoas relacionadas ao grupo de delinqüentes. Após o policial, fala, então, uma prostituta cinqüentona que foi "adotada" por um dos delinqüentes, e faz seu relato à polícia sobre o crime e os criminosos, mas, como no discurso anterior, o texto é pleno de depoimentos pessoais. A narradora chega a misturar a própria história

\footnotetext{
${ }^{1}$ ANTUNES, 2007, p. 16.
} 
com a do policial dos primeiros capítulos, que retorna ao final do sexto capítulo, entremeando sua fala com a da depoente anterior.

Comparecem então outras vozes, que têm alguma ligação com o crime: a mãe de um dos jovens, um homem que se diz seu marido, a irmã de um dos criminosos, um velhote viúvo casado com ela, um homem que havia sido apresentado aos mestiços pelo irmão, que fazia parte da gangue, um dos pivetes e sua mãe, uma mestiça casada com um policial. São dezenove capítulos em que não há uma seqüência lógica, em que os próprios depoentes são de difícil identificação, em que passado e presente se alternam sem conexões lógicas, em que as vozes dos discursos se misturam sem identificação precisa.

No décimo sétimo capítulo, o antepenúltimo, o policial do início retorna e propõe-se organizar a desordem da escrita, tentando prender o texto em alíneas, de A) a $Z$ ). Esse narrador agora clama pela manutenção da ordem, tanto social quanto escritural, e ambas as tentativas falham: ele não consegue prender nem os delinqüentes nem o relato, e as frases escorrem por entre as alíneas sem a objetividade que pretendiam. O narrador admite o fracasso: "renunciei às palavras e o que digo são ecos do silêncio". ${ }^{2}$

Sabe-se pelos depoimentos que vários dos delinqüentes morrem, muitos deles traídos pelos próprios parentes ou pessoas que lhes são próximas. As notícias sobre os desdobramentos, entretanto, não obedecem a uma lógica, a uma seqüência, mas aparecem aqui e ali em meio aos delírios dos locutores.

É curioso que os relatores não apenas falam, mas escrevem; todos escrevem o tempo todo, mas não conseguem dizer nada com suas palavras, seu discurso é um fracasso. Todos têm problemas com a escritura: um declara que detesta o que escreve; outro luta para "escrever decentemente"; um terceiro lamenta o quão complicado é escrever; outro despede-se ao final de sua fala esperando voltar em um livro vindouro; adiante um outro dá instruções aos leitores; todos se sentem aborrecidos, contrariados, incompletos. Entre relatos "oficiais", depoimentos testemunhais, desabafos, pretensões a uma bela escritura, desnuda-se, no meio do romance, o processo da narrativa:

\footnotetext{
${ }^{2}$ ANTUNES, 2007, p. 331.
} 
Estou a fazer um livro, a mão escreve o que as vozes lhe ditam e tenho dificuldade em escutá-las, se as vozes ditam não é mentira, é tal qual, o meu irmão e eu ordenam elas, e portanto ponho o meu irmão e eu a cavarmos um buraco, não, ponho o meu irmão a cavar um buraco e eu distraído com os pássaros, assim está certo. ${ }^{3}$

Esse pequeno trecho mostra a verdade da escritura, o que "está certo", que "não é mentira", que é "tal qual". A verdade ficcional, portanto, não depende de verificação: ela está naquilo que as vozes ditam ao escritor, e assim se faz uma narrativa.

No último capítulo, um dos menores criminosos, o de treze anos, fala de sua detenção por sete meses em um instituto de recuperação de menores, e nas últimas páginas, na seqüência de um ditado que um professor faz para os menores no instituto, uma voz masculina sugere que aquela escrita é um ditado, confirmando o que a outra voz (ou a mesma?) da citação acima diz sobre o processo de criação.

O romance assume, assim, a configuração de um ditado, que contém verdades porque as vozes ficcionais não mentem, são a verdade da mentira. E, por mais que um dos narradores tente enquadrar os fatos de A a $\mathrm{Z}$, mesmo que outra voz diga que o final do ditado (equiparado aqui a um suplício) se aproxima, a escrita não tem fim, sempre haverá quem fale algo mais: "entrego assunto a quem falou antes de mim ou àqueles que porventura vierem depois uma vez que há sempre quem venha depois corrigir o que dissemos". ${ }^{4}$

O meu nome é Legião é, assim, bastante contemporâneo em sua estética da falta, da ausência, da impossibilidade de os extremos e os meios se encontrarem para compor um conjunto lógico. A multiplicidade de enunciadores, todos eles instáveis e descrentes do poder edificante da escritura, impede a identificação de uma voz "central" (ou a que deveria ser o centro, que não há). O clímax e o desenlace clássicos não mais constituem o apelo da narrativa, que não aponta para uma solução, uma decisão, um ponto de chegada qualquer. A desmaterialização da trama narrativa mostra estruturas

\footnotetext{
${ }^{3}$ ANTUNES, 2007, p. 265.

${ }^{4}$ ANTUNES, 2007, p. 376.
} 
corroídas internamente por fatias, entremeadas de vazios, parecendo fadadas à auto-destruição, ao despedaçamento. A forma é ditada pela lógica interna da obra: embora sejam dezenove capítulos mais ou menos equivalentes em tamanho, as relações entre eles são definidas pelo próprio texto, sem nenhuma organização que defina $a$ priori o que se pode esperar dos acontecimentos. Um traço adicional de contemporaneidade é a revelação dos bastidores da escrita, que apresentam uma problematização direta do processo criativo. Considerando essa tendência de errância e dispersão, percebe-se que o real aqui perde seu poder ordenador do texto literário, que recusa o tempo teleológico. Esse indeferimento do referencial coloca em sua ausência a heterogeneidade, a diferença - ou a indiferença -, a fragmentação, a indeterminação, o relativismo. Apesar de acompanharmos de perto a trajetória de Lobo Antunes, não é sem perplexidade que lemos mais esse romance, no sentido de que ficamos sempre na expectativa de como o autor continuará essa tendência de eliminação da trama e de celebração da linguagem, e, sendo assim, pergunta-nos sempre o que virá a seguir, e aonde isso vai parar. Com relação ao prazer da leitura, ao envolvimento do leitor, traços sempre presentes nessa escritura instigante, arriscaríamos dizer que Lobo Antunes teve momentos mais emocionantes nessa que podemos chamar fase mais recente, como em Não entres tão depressa nesta noite escura e em Eu bei-de amar uma pedra. É lícito, entretanto, esperar tudo deste que é inegavelmente um nome superlativo da ficção em língua portuguesa. 